Article

\title{
Hydrodynamic and Flotation Kinetic Analysis of a Large Scale Mechanical Agitated Flotation Cell with the Typical Impeller and the Arc Impeller
}

\author{
Zhengchang Shen ${ }^{1,2}$, Ming Zhang ${ }^{1,2,3, *}$, Xuesai Fan ${ }^{1,2}$, Shuaixing Shi ${ }^{1,2}$ and Dengfeng Han ${ }^{1,2}$ \\ 1 Beijing Engineering Research Center on Efficient and Energy Conservation Equipment of Mineral \\ Processing, BGRIMM Machinery \& Automation Technology Co. LTD., Beijing 100160, China; \\ shen_zc@bgrimm.com (Z.S.); fanxuesai@bgrimm.com (X.F.); shi_sx@bgrimm.com (S.S.); \\ handengfeng@bgrimm.com (D.H.) \\ 2 State Key Laboratory of Mineral Processing, BGRIMM Technology Group, Beijing 100160, China \\ 3 School of the Mechanical Engineering, University of Science and Technology Beijing, Beijing 100083, China \\ * Correspondence: zhangming@bgrimm.com
}

Received: 29 November 2018; Accepted: 22 January 2019; Published: 29 January 2019

\begin{abstract}
The processing of low grade mineral ores using large scale flotation cells is obviously more advantageous than smaller-scale processing. Large-scale flotation cells have become increasingly important for effective volume scale-up. In this study, the latest and largest flotation cell in China, with an effective volume of $680 \mathrm{~m}^{3}$, is considered. Hydrodynamics and flotation kinetics analyses are conducted using computational fluid dynamics (CFD) simulation. It is demonstrated that the flotation cell with a typical impeller produces suitable hydrodynamics for mineral particles based on analysis of the flow pattern, gas dispersion and solid suspension. The performance of the large-scale flotation cell is studied using hydrodynamic performance parameters. The variation of the performance parameters, such as the power number $\left(N_{p}\right)$, the Froude number $\left(F_{r}\right)$, the air flow number $\left(N_{a}\right)$, and so on, with the flotation cell volumes, followed trends similar to that of previous cells of a different size, which were proven to be effective for engineering applications. To decrease the detachment of mineral particles, a new type of impeller, for which the impeller plate is a hyperbolic curve, viz. an arc impeller, was developed. Compared with the typical impeller, the arc impeller expands and lifts the low circulating flow, thereby shortening the transportation distance of the mineral particles. The data indicates that kinetic eddy dissipation plays a key role in determining the collision kernel and collision probability profile. The newly designed arc impeller leads to a higher collision probability than the typical impeller, resulting in better flotation performance. This research should aid in the optimization of the structure of the $680 \mathrm{~m}^{3}$ flotation cell.
\end{abstract}

Keywords: scale-up; computational fluid dynamics simulation; hydrodynamics number; flotation kinetics; optimization

\section{Introduction}

Froth flotation is a technique that is used extensively in the mineral industry, to process most metallic minerals. The proportion of low-grade ores has increased with the global depletion of mineral resources. The increased capacity of concentrators has escalated the demand for large-scale flotation cells [1]. Therefore, flotation equipment has undergone a significant increase in size, where large-scale flotation cells have prominent advantages for improving metallurgical performance, reducing the area of the plant blueprint, lowering the power consumption of the unit ore and decreasing labor cost. Since the end of the 1940s, there has been a trend towards the scale-up of flotation cells. At the end of the 1990s, a flotation cell with an effective volume of $200 \mathrm{~m}^{3}$ was developed. In the last two 
decades, flotation cells have undergone a dramatic increase in size. In 2007, the first $300 \mathrm{~m}^{3}$ Tank Cell flotation cell was designed and was industrially applied to Macraes gold ore, New Zealand [2]. Furthermore, $320 \mathrm{~m}^{3}$ BGRIMM (Beijing General Research Institute of Mining and Metallurgy) flotation cells are also in operation in Toromocho Copper Mine, Peru and Wunugetushan Copper Mine, China [3]. Flotation cells are conventionally designed using empirically-derived relations and geometric similarity. The continual scale-up of flotation cells is still a significant developing prospect. A $500 \mathrm{~m}^{3}$ Tank Cell flotation cell was designed for the industrial experiment in Finland and a $620 \mathrm{~m}^{3}$ Tank Cell flotation cell has also been completed in the design [4]. A $660 \mathrm{~m}^{3}$ Super Cell flotation cell was manufactured for the industrial experiment released at the Procemin conference in 2015 [5]. Thus, the development of a flotation cell with a volume exceeding $600 \mathrm{~m}^{3}$ has become a notable and crucial research field for researchers worldwide.

Table 1 summarizes the key research about computational fluid dynamics (CFD) simulation and scale-up of flotation cells, not including other fields such as reagents, molecular computing, the flotation process, and so on. Due to the weakening of mineral resources, major organizations have devoted themselves to the engineering applications of large flotation cells and the development of the new stirred mechanism. In the early stages, researchers studied the method of scale-up for flotation cells based on hydrodynamic numbers and engineering experience. With the application of large flotation cells worldwide, the CFD method is used in flotation cell design and optimization [6]. The CFD method provides more detailed information on the flow than previous experimental research, especially for large-scale flotation cells. Thus, the key components of the flotation cell, the impeller and stator, are the one of key points of the research.

Computational fluid dynamics (CFD) has become a popular approach for the research and design of flotation cells [7]. A review of CFD simulation in flotation cells was summarized by Wang et al. [8]. Numerical simulations have been conducted to study the single-phase flow field in a $0.8 \mathrm{~m}^{3}$ "Metso Mineral" cell and the overall flow characteristics are provided [9]. A comparative study of three turbulence models which predicted the flows in a Tank Cell flotation cell was conducted, and the local flow field of the rotor-stator mechanism was presented [10]. CFD has been used to model single-phase and two-phase flows in Dorr-Oliver flotation cells, from laboratory models to full-scale machines [11]. Multiphase flow numerical simulation was carried out to investigate the air dispersion and solid suspension in a Tank Cell flotation cell [12]. The effects of the impeller angle were analyzed in a $0.2 \mathrm{~m}^{3}$ pilot KYF flotation cell by CFD and Particle Image Velocimetry (PIV) [13]. The CFD results were consistent with the PIV measurement. Further, A CFD-based flotation model was developed to predict the flotation kinetics in the flotation cell. The connecting of hydrodynamics and flotation kinetics using the CFD simulation is an elegant innovation. The recovery and flotation probability can be obtained for various particle diameters [14]. Thus, many researchers have devoted themselves to optimizing the flotation cell using numerical simulation.

In order to estimate the properties of the flotation cell, a series of hydrodynamic numbers are established to analyze the hydrodynamics characteristics [15]. Arbiter proposed seven important hydrodynamic numbers, including the power number, circulation capacity, flow number, and so on [16]. Zlokarnik summarized 24 dimensionless numbers for mineral processing and chemical engineering, including the Reynolds number, Prandtl number, Froude number, and so on [17]. The designs of the Wemco and Tank Cell flotation cells are based on the previous hydrodynamic criteria. In recent years, Yianatos et al. (2006-2012) calculated the effective mean residence time for the industrial cells from the residence time distribution (RTD) measurements to evaluate the industrial flotation cell [1,18-22]. The investigation of flotation cells via hydrodynamic and flotation kinetic analysis has become a rising trend. 
Table 1. The summary of the computational fluid dynamics (CFD) simulation and scale-up of flotation cells.

\begin{tabular}{|c|c|c|}
\hline Research & Comment & Author/Organization \\
\hline \multirow{3}{*}{$\begin{array}{l}\text { Large flotation } \\
\text { application }\end{array}$} & $\begin{array}{l}\text { Tank cell flotation cells scale-up from } 60-620 \mathrm{~m}^{3} \text { in } 1960 \mathrm{~s}-\text { now; } \\
\text { The new flotation force impeller was developed }\end{array}$ & Outotec company \\
\hline & $\begin{array}{l}\text { Dorroliver/Wemco flotation cells scale up to } 660 \mathrm{~m}^{3} / 300 \mathrm{~m}^{3} \text {. } \\
\text { The next step impeller and stator was developed }\end{array}$ & FLSmidth company \\
\hline & $\begin{array}{l}\text { KFY /JJF flotation cells scale up to } 680 \mathrm{~m}^{3} / 320 \mathrm{~m}^{3} \text { from } \\
\text { 1990-2018. The arc impeller and other newly designed impeller } \\
\text { are developing }\end{array}$ & BGRIMM company \\
\hline \multirow{5}{*}{$\begin{array}{l}\text { Scale-up method } \\
\text { of flotation cell }\end{array}$} & $\begin{array}{l}\text { hydrodynamic numbers are established to analyze the } \\
\text { hydrodynamics characteristics in Wemco flotation cell }\end{array}$ & Nelson [15] \\
\hline & Propose seven important hydrodynamic numbers to scaling up & Arbiter [16] \\
\hline & $\begin{array}{l}\text { summarized } 24 \text { dimensionless numbers for mineral processing } \\
\text { and chemical engineering }\end{array}$ & Zlokarnik [17] \\
\hline & $\begin{array}{l}\text { Based on the RTD research to scale up and optimize large } \\
\text { flotation cell }\end{array}$ & Yianatos et al. [18-20,22] \\
\hline & $\begin{array}{l}\text { Scale-up method of BGRIMM flotation cell based on four } \\
\text { scale-up numbers }\end{array}$ & Shen et al. $[23,24]$ \\
\hline \multirow{4}{*}{ Kinetic model } & $R(t)=R_{\max }\left(1-\mathrm{e}^{-k t}\right)$ & Garcfa-Zuniga [25] \\
\hline & $R=R_{\infty} \frac{R_{c} R_{f}}{R_{c} R_{f}+\left(1-R_{c}\right)}$ & Dobby \& Finch [26] \\
\hline & $R(t)=R_{\max } \iint_{0}^{\infty}\left(1-e^{-k t}\right) f(k) E(t) d k d t$ & Yianatos $[1,21]$ \\
\hline & $\frac{d N_{p}}{d t}=-k N_{p}$ & Ahmed and Jameson [27] \\
\hline \multirow{3}{*}{ CFD model } & $\begin{array}{c}\text { Single phase: } \\
\text { Continuity: } \\
\frac{\partial \rho}{\partial t}+\nabla \cdot \rho u=0 \\
\text { Momentum: } \\
\frac{\partial \rho u}{\partial t}+\nabla \cdot \rho u u=-\nabla p+\nabla \cdot\left(\mu_{L, i}+\mu_{T, i}\right)\left(\nabla u_{i}+\left(\nabla u_{i}\right)^{T}+\rho g\right.\end{array}$ & \multirow{3}{*}{ Wang et al. [8] } \\
\hline & $\begin{array}{c}\text { Euler-Euler: } \\
\text { Continuity: } \\
\frac{\partial\left(\alpha_{i} \rho_{i}\right)}{\partial t}+\nabla \cdot \alpha_{i} \rho_{i} u_{i}=S_{i} \\
\text { Monentum: } \\
\frac{\partial\left(\alpha_{i} \rho_{i} u_{i}\right)}{\partial t}+\nabla \cdot\left(\alpha_{i} \rho_{i} u_{i} u_{i}\right)= \\
\nabla \cdot\left[\alpha_{i}\left(\mu_{L, i}+\mu_{T, i}\right)\left(\nabla u_{i}+\left(\nabla u_{i}\right)^{T}\right)\right]+\alpha_{i}\left(f_{i}-\nabla p_{i}\right)+F_{i}+S_{i} u_{i} \\
F_{i}=F_{d}+F_{A}+F_{L}+F_{T}+F_{\text {other }}\end{array}$ & \\
\hline & $\begin{array}{c}\text { Euler-Lagrangian: } \\
\text { Continuity: } \\
\frac{\partial \rho}{\partial t}+\nabla \cdot \rho u=0 \\
\text { Monentum: } \\
\begin{array}{c}\frac{\partial \rho u}{\partial t}+\nabla \cdot \rho u u=-\nabla p+\nabla \cdot\left(\mu_{L, i}+\mu_{T, i}\right)\left(\nabla u_{i}+\left(\nabla u_{i}\right)^{T}\right)+\rho g \\
\text { Continuity: } \\
\frac{\partial\left(\alpha_{l} \rho\right)}{\partial t}+\nabla \cdot \alpha_{l} \rho u=0 \\
\text { Monentum: } \\
\frac{\partial\left(\alpha_{l} \rho u\right)}{\partial t}+\nabla \cdot \alpha_{l} \rho u u= \\
-\alpha_{l} \nabla p+\alpha_{l} \nabla \cdot\left(\mu_{L, i}+\mu_{T, i}\right)\left(\nabla u_{i}+\left(\nabla u_{i}\right)^{T}\right)+\alpha_{l} \rho g \\
\text { Particle or bubble motion: } \\
m_{i} \frac{d u_{i}}{d t}=F_{d}+F_{p}+F_{G}+F_{\text {other }}\end{array}\end{array}$ & \\
\hline
\end{tabular}


Table 1. Cont.

\begin{tabular}{|c|c|c|}
\hline Research & Comment & Author/Organization \\
\hline \multirow{6}{*}{ CFD simulation } & $\begin{array}{l}\text { Flow pattern research including mixing, air bubbles dispersion } \\
\text { and so on, such as air forced flotation cell of TankCell, KYF, } \\
\text { Dorr-Oliver flotation cell }\end{array}$ & $\begin{array}{l}\text { Salem-Said et al. [28]; } \\
\text { Tiitinen [12,29]; } \\
\text { Xia et al. [10]; } \\
\text { Shen et al. [30]; }\end{array}$ \\
\hline & Self-induced flotation cell research on air suction, flow pattern & Fayed and Ragab [31] \\
\hline & $\begin{array}{l}\text { Particle-air bubbles collision, adherin, detachment research } \\
\text { predict the metallurgical performance }\end{array}$ & Koh and Schwarz $[7,32-35]$ \\
\hline & Recovery simulation would be compared with experiment & Koh and Schwarz [14] \\
\hline & CFD model verification using experimental data & Shi et al. [13] \\
\hline & Optimized of flotation cell of structure & Zhou et al. [36] \\
\hline
\end{tabular}

where $R_{\max }\left(R_{\infty}\right)$ : the theoretical maximum recovery achievable, considering the equipment effciency and mineral liberation; $t$ : time; $k$ : flotation constant; $R_{c}$ : the recovery from the collection zone; $R_{f}$ : the recovery from froth zone; $E(t)$ : the residence time distribution; $f(k)$ : the flotation rate distribution; $N_{p}$ is the number of free particles in the pulp phase; $u$ : velocity vector; $\rho$ : density; $t$ : time; $p$ : pressure; $g$ : gravity vector; $\alpha$ : phase volume fraction; $\mu$ : dynamic viscosity; $F$ : inter-phase force; $F_{d}$ : the drag force; $F_{A}$ : the virtual mass force; $F_{L}$ : the lift force; $F_{T}$ : the turbulence dispersion force; $F_{\text {other }}$ : the other force; $f$ : body force; $S i$ : source term. The subscript: $i$ : represents for each phase; $l$ : liquid; g: gas; $d$ : drag; $p$ : pressure gradient; G: gravity.

In this study, a $680 \mathrm{~m}^{3}$ BGRIMM flotation cell is initially designed using empirically-derived relations, and CFD simulations are used to provide more details for further study. Multiphase flow numerical simulations are implemented to investigate the hydrodynamics and flotation kinetics of the large-scale flotation cell. The variation of the hydrodynamic numbers such as the power number $\left(N_{p}\right)$, the Froude number $\left(F_{r}\right)$, the air flow number $\left(N_{a}\right)$, and so on, with volume scale-up, suggests good performance of the large-scale flotation cell. To decrease the detachment of the mineral particles in the large-scale flotation cell, a newly designed impeller, for which the impeller plate is a hyperbolic curve, namely an arc impeller, is developed. A comparison of the effects of the typical impeller and arc impeller on the hydrodynamics and flotation kinetics is also presented. This research should aid the optimizing of the structure of the $680 \mathrm{~m}^{3}$ flotation cell.

\section{Model Description}

\subsection{Hydrodynamic Numbers of Flotation Cells}

The design of a large-scale flotation cell has been primarily based on geometric similarity, dimensional analysis and empirical relations, employing dimensionless numbers, with the objective to achieve a flow pattern, air dispersion and solid suspension on different scales [19]. Six hydrodynamic numbers are listed in Table 2, these parameters can be used to evaluate the performances of the flotation cell. The power number is a significant dimensionless factor that indicates the effects of variation of the cell structure on the power consumption. The power number is also a critical factor for the scale-up of stirred equipment in mineral processing and chemical engineering. For cells of different scales, the power number remains almost the same. The power intensity is a criterion that is used to evaluate the power consumption per unit volume, and reflects the economy of the flotation equipment. The circulation capacity indicates the fluid pump effect at a given time interval and indicates the relationship between the effective volume of the cell and the pumping effect. Moreover, it can represent the collision probability of particles and bubbles. The Froude number, the ratio between the centrifugal or inertial forces due to the pumping action of the impeller and the gravitational forces due to the hydrostatic head in a flotation cell, is another important and similar factor. This number can be used to estimate the solid suspension to some extent. The air flow number defines the critical ratio between the air flow rate and the impeller pumping rate regardless of the cell size and represents the upward velocity of the bubbles. The air capacity number represents the total air holdup, indicating the aeration intensity. 
Table 2. The typical hydrodynamic performance parameters for flotation cell.

\begin{tabular}{cc}
\hline Parameter & Definition \\
\hline Power Number, $N_{p}$ & $P / \rho N^{3} D^{5}$ \\
Power intensity & $P / V$ \\
Circulation Intensity & $Q_{r} / N D^{3}$ \\
Froude Number, $F_{r}$ & $N^{2} D / g$ \\
Air Capacity Number, $C_{a}$ & $Q / N D^{3}$ \\
Air Flow Number, $N_{a}$ & $Q / A_{c} V_{t}$ \\
\hline
\end{tabular}

where $P$ : the net power input in the water system; $\rho$ : density; $N$ : rotation; $D$ : the diameter of the cell; $g$ : the acceleration due to gravity; $V$ : the effective volume of the flotation cell; $Q\left(\mathrm{~m}^{3} / \mathrm{s}\right)$ : the gas volumetric flow; $Q_{r}$ : the circulation volume of the impeller; $A_{c}$ : the area of the cross section in the flotation cell; $V_{t}$ : the velocity maximum of the impeller.

\subsection{Flotation Kinetics}

Flotation is a complicated process that is not only a multiphase flow but also a physical and chemical process. For simplification, flotation is generally regarded as a first-order process considering the interaction of air bubbles and mineral particles as follows:

$$
\frac{d N_{p}}{d t}=-z_{1} N_{p} N_{b} P_{c} P_{a} P_{s}
$$

where $N_{p}$ and $N_{b}$ : the particle and bubble number concentrations; $P c, P a$ and $P_{s}$ : the probabilities of particle-bubble collision, adhesion and stabilization against external forces; $z_{1}$ : the particle-bubble collision kernel.

$$
Z_{p b}=-z_{1} N_{p} N_{b}
$$

where $Z_{p b}$ is the particle-bubble collision rate in turbulent flow and is dependent on the size of the particles and bubbles.

Abrahamson [37], Schubert and Bischofberger [38] have proposed the following equation for the particle-bubble collision kernel.

$$
z_{1}=5.0\left(\frac{d_{p}+d_{b}}{2}\right)^{2}\left(U_{p}^{2}+U_{b}^{2}\right)^{1 / 2}
$$

where $d_{p}$ : the particle diameter; $d_{b}$ : the bubble diameter; $U_{p}$ : the turbulent fluctuating velocity of the particle relative to the fluid; $U_{b}$ : the turbulent fluctuating velocity of the bubble relative to the fluid.

Schubert and Bischofberger [38] reported that these parameters are related to the local turbulent dissipation rate.

$$
U_{i}=\frac{0.4 \varepsilon^{4 / 9} d_{i}^{7 / 9}\left(\frac{\rho_{i}-\rho_{f}}{\rho_{f}}\right)^{2 / 3}}{v^{1 / 3}}
$$

where $\varepsilon$ is the turbulent dissipation rate per unit mass, $v$ is the kinematic viscosity, $q_{f}$ is the fluid density, and $q_{i}$ is the density of the particle $(p)$ or bubble $(b)$. In the equation, we assumed the $q_{b}=0.5 q_{f}$.

The collision probability is a significant parameter that indicates the performance of flotation cells. Yoon and Luttrell [39] defined the collision probability as follows:

$$
P_{c}=\left(1.5+\frac{4}{15} R e_{b}^{0.72}\right) \frac{d_{p}^{2}}{d_{b}^{2}}
$$

The bubble Reynolds number $\left(R e_{b}\right)$ is given as follows.

$$
\operatorname{Re}_{b}=\frac{d_{b} \sqrt{U_{b}^{2}}}{v}
$$




\subsection{Geometry and CFD Model}

This study was conducted using a mechanical agitated flotation cell with an effective volume of $680 \mathrm{~m}^{3}$ which is developed by BGRIMM. The large-scale flotation cell consists of a tank with an inner diameter of $11,000 \mathrm{~mm}$ and a tank height of $8500 \mathrm{~mm}$. The speed of the impeller is about 7-9 m/s which is determined by mineral properties. The two types of impellers were introduced into the large-scale flotation cell in this study. The typical impeller features a horizontal impeller plate that has been proven to exhibit good performance in engineering applications (Figure 1). The newly designed impeller, namely the arc impeller, features a hyperbolic curve at the impeller plate for improving the performance of the large-scale flotation cell (Figure 2).

The numerical approaches for multiphase flow can be classified roughly into direct numerical simulation (DNS), Euler-Lagrange, and Euler-Euler models. The Euler-Euler approach is more practical and appropriate for the high gas volume fraction system, in which both phases are modeled by volume-averaged equations. The movement of the different continuous phases is described by solving the corresponding Reynolds averaged Navier-Stokes equations (Table 1).

The overall dimensions of the model were established, in which the model is meshed with hexahedral grids. As the geometrical size becomes increasingly large, the advantages of the structured mesh for reducing the mesh number, improving the mesh quality and reducing computational expense become obvious when compared with the unstructured mesh. The entire flotation cell mesh consists of $1.2 \times 10^{6}$ units, as is illustrated in Figure 1. Mesh quality is above 0.4 using the criterion "determinant $2 \times 2 \times 2$ " in the ICEM software. Grid refinement tests showed less than $10 \%$ difference in the results predicted with finer meshes.

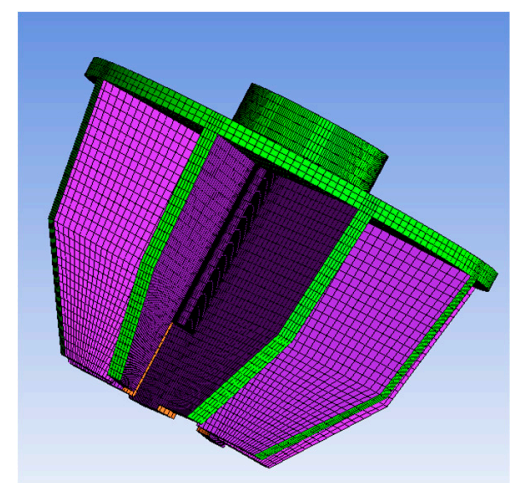

(a)

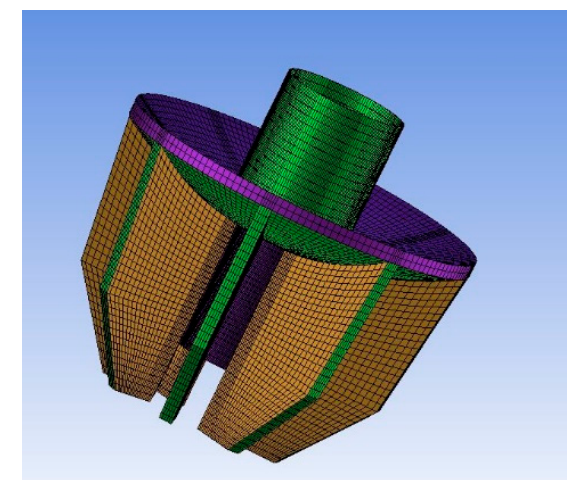

(b)

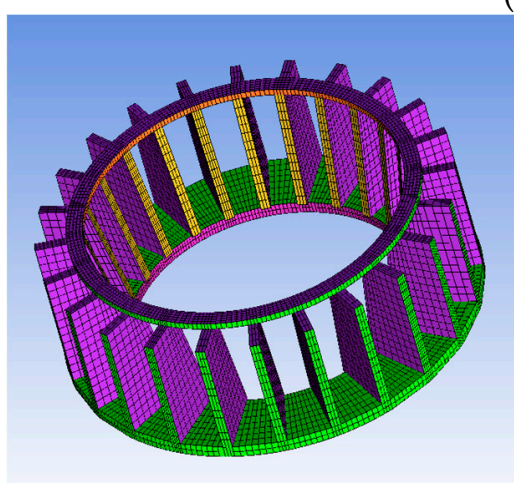

(c)

Figure 1. (a) The mesh of the typical impeller; (b) The mesh of the arc impeller; (c) The mesh of the stator.

In the single phase simulation, the wall boundary condition is imposed on the top of the weir slip. However, in the multiphase flow simulation, the degassing boundary condition is imposed to allow only air to escape. Water is defined as a continuous fluid. Both air bubbles and mineral particles are 
considered to be dispersed fluids. The air bubbles have a uniform diameter of $2 \mathrm{~mm}$. The drag force and surface tension are taken into account for the interface forces between the gas and liquid. The drag model uses the drag coefficient with 5 . The other phase interactions, such as lift force, virtual mass force, turbulence dispersion force, and so on, are not considered in this study. The surface tension is $0.072 \mathrm{~N} \cdot \mathrm{m}^{-1}$. For solid and liquid phase, the mineral particles are defined as a dispersed solid, and the uniform diameter is $0.074 \mathrm{~mm}$. The mass concentration is $36 \%$ (volume fraction $15 \%$ ). The ore density is $2650 \mathrm{~kg} / \mathrm{m}^{3}$ and the viscosity of the pulp is $3 \mathrm{mPa} \cdot \mathrm{s}$. The drag model of the Wen Yu model was selected for the interface force between the solid and liquid. The particle suspension may cause local high solid fractions, such as near the bottom of the tank. The Wen Yu model is valid for solid phase volume fractions up to 0.2. Thus, other phase interactions between solid and liquid were not considered. CFD simulations were implemented using computational fluid dynamics code CFX 14.0. It is suitable that the standard $k-\varepsilon$ turbulence model is used in a flotation cell simulation for liquid phase. $C_{1 \varepsilon}, C_{2 \varepsilon}$ and $C_{3 \varepsilon}$ are the model constants in the turbulence kinetic energy transport equation and the turbulence energy dissipation transport equation in Table 3 . The estimated Reynolds Number $\left(N D^{2} \rho / \mu\right)$ would be $5.7 \times 10^{6}$. This means it is fully turbulent in the major region of the flotation cell. For liquid and solid phase, the density difference and dispersed phase zero equation was selected.

Table 3. Turbulence model constants.

\begin{tabular}{ccccccc}
\hline Constant & $C_{\mu}$ & $C_{1 \varepsilon}$ & $C_{2 \varepsilon}$ & $C_{3 \varepsilon}$ & $k$ & $\sigma \varepsilon$ \\
\hline Value & 0.09 & 1.44 & 1.92 & 1.0 & 0.4187 & $\frac{k^{2}}{\left(C_{2 \varepsilon}-C_{1 \varepsilon}\right) C_{\mu}^{0.5}}$ \\
\hline
\end{tabular}

In the CFD model of flotation cell is divided into multiple zones, such as the rotating impeller and stationary tank that are separated by interface boundaries. The Multiple Reference Frame model (MRF) approach was used to model the impeller rotating in the stationary tank. All equations are calculated by using high resolution and the residual RMS of equation was about $1 \times 10^{-3}$ to $1 \times 10^{-4}$. The velocity fluctuation of the monitoring point was about $10 \%$. The detailed information about CFD is summarized in Tables 4 and 5. The numerical simulations are conducted in National Supercomputer Center in Tianjin, China.

Table 4. CFD simulation settings.

\begin{tabular}{cc}
\hline Single Phase & Multiphase \\
\hline Mesh type & Structure mesh \\
Analysis type & Steady stead \\
Phase & Water for continous fluid; air for dispersion fluid; solid for dispersion solid \\
Model & $\mathrm{K}-\varepsilon$ model for liquid; dispersed phase zero equation for liquid \\
Multiple zone & The Multiple Reference Frame model (MFR) \\
\hline
\end{tabular}

Table 5. CFD simulation initial and boundary conditions.

\begin{tabular}{|c|c|c|}
\hline & Single Phase & Multiphase \\
\hline Mesh zone & \multicolumn{2}{|c|}{$\begin{array}{c}\text { Move zone with rotating of } 90 \mathrm{rpm} \text { including impeller; stationary zone including stator } \\
\text { and tank }\end{array}$} \\
\hline Interface & \multicolumn{2}{|c|}{ Connecting move zone and stationary zone with GGI } \\
\hline Materials & \multicolumn{2}{|c|}{ Water; air bubbles of $2 \mathrm{~mm}$, particles of $0.074 \mathrm{~mm}, 2650 \mathrm{~kg} / \mathrm{m}^{3}, 3 \mathrm{mPa} \cdot \mathrm{s}$} \\
\hline Boundary & $\begin{array}{l}\text { Wall at the top of tank; } \\
\text { others as wall }\end{array}$ & $\begin{array}{l}\text { Degassing at the top of tank as air outlet; } \\
\text { Air inlet at the impeller; others as wall }\end{array}$ \\
\hline Initial & $\begin{array}{l}100 \% \text { of water; Pressure } 1 \mathrm{~atm} \text {; } \\
\text { velocity } 0 \text {; Turbluence: } \\
\text { medium (intensity } 5 \% \text { ) }\end{array}$ & $\begin{array}{c}\text { The simulation result of the single phase; } \\
\text { Gas liquid simulation: the volume fraction of water } 1 \text {, } \\
\text { the volume fraction of gas } 0 ; \\
\text { Gas-liquid-solid simulation: } 15 \% \text { of solid, } 85 \% \text { of water, } \\
\text { no air for initial }\end{array}$ \\
\hline Solution & \multicolumn{2}{|r|}{ High resolution in CFX software } \\
\hline
\end{tabular}




\section{Results and Discussion}

\subsection{Hydrodynamics of the Large Flotation Cell}

\subsubsection{Flow Pattern}

It is important to produce a suitable flow pattern in a large-scale flotation cell. Figure 2 illustrates the streamline at the center section of the flotation cell with a typical impeller. A circulating flow similar to that of the previous BGRIMM flotation cell was formed, which is a suitable fluid dynamics environment. The upper circulating flow is larger, with a relatively lower velocity than the lower circulating flow. The fluid is thrust away from the impeller blades and is pumped into the impeller zone due to the negative pressure. The turbulent dissipation rate reflects the flow intensity in the flotation. As is shown in Figure 3, the turbulence eddy dissipation at the center is high in the impeller zone and it is obviously low in other regions.

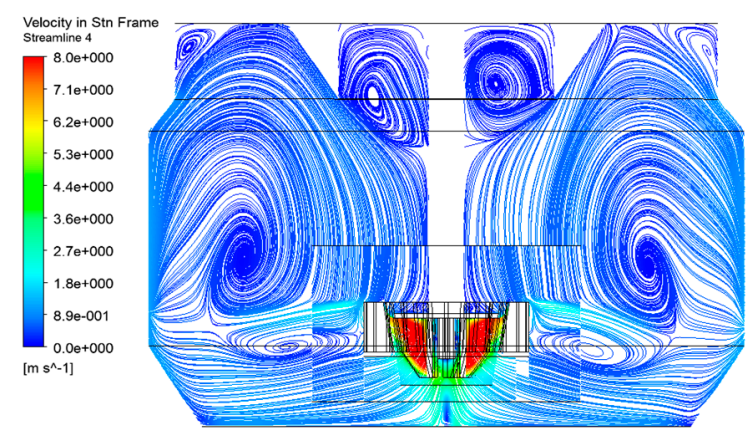

Figure 2. Velocity streamline profile at the center section.

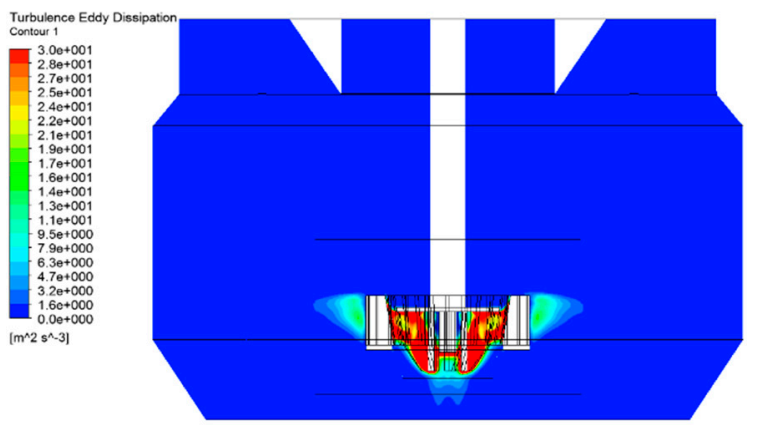

Figure 3. Turbulence eddy dissipation at the center section.

\subsubsection{Gas Dispersion and Solid Suspension}

Air dispersion and solid mixing are fundamental functions of flotation cells. Figure 4 presents the air dispersion at the center section of the flotation cell with a typical impeller, where the superficial velocity of the air is $2.5 \mathrm{~cm} / \mathrm{s}$. Air is well dispersed inside the cell, but the air holdup is quite low in the lower cell for buoyancy. Figure 5 shows the mixing of conventional particles with a size of $0.074 \mathrm{~mm}$. There is a very low solid holdup region at the top of the flotation cell. This demonstrates that the mineral particles are brought to the top region and attached to the air bubbles in the actual flotation cell. Thus, high solid holdup appears under the impeller. This agrees with engineering practice where solid suspending is uniform in the major region of the flotation cell. The large-scale flotation cell developed produces excellent air dispersion and solid mixing. 


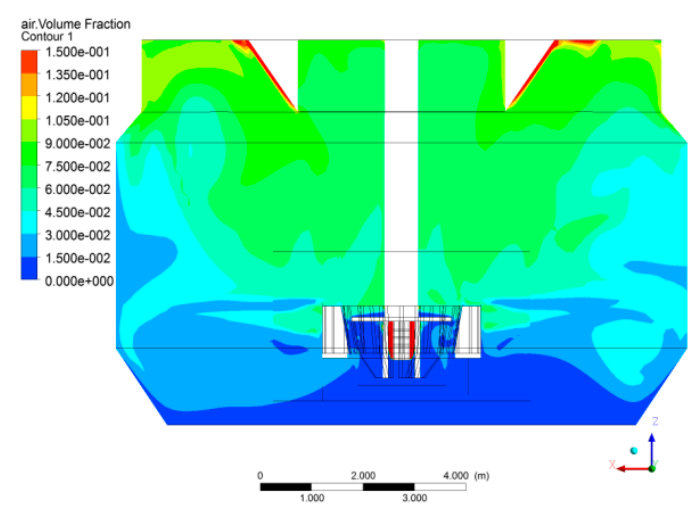

Figure 4. Air volume fraction profile.

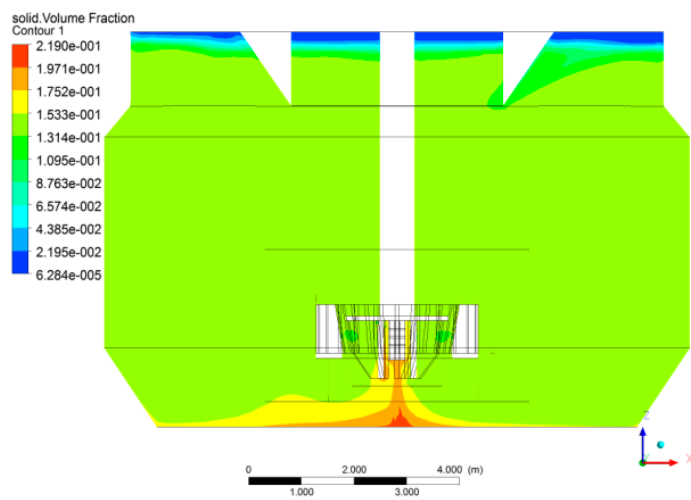

Figure 5. Solid volume fraction profile.

\subsubsection{Analysis of Hydrodynamics Performances}

Figure 6 shows the relationship between the flotation volume and power number or power intensity. For flotation cell volume ranging from 70 to $680 \mathrm{~m}^{3}$, the power number remines at about 5.4, illustrating a good balance between the volume and power during the cell scale-up. Generally, the power intensity decreases as the volume increases. This observation suggests the obvious advantages of reducing the power consumption and lowering the operation cost. The power intensity of the $680 \mathrm{~m}^{3}$ flotation cell is lightly higher than that of $320 \mathrm{~m}^{3}$ flotation cell. As shown in Figure $1 \mathrm{c}$, a circular ring was positioned on top of the stator blades to maintain the structural stability where the stator blades are longer than those ever used in the previous cells. It is also very important to minimize the effect of the circular ring on the flow pattern. The new design may increase the power consumption of the large-scale flotation cell.

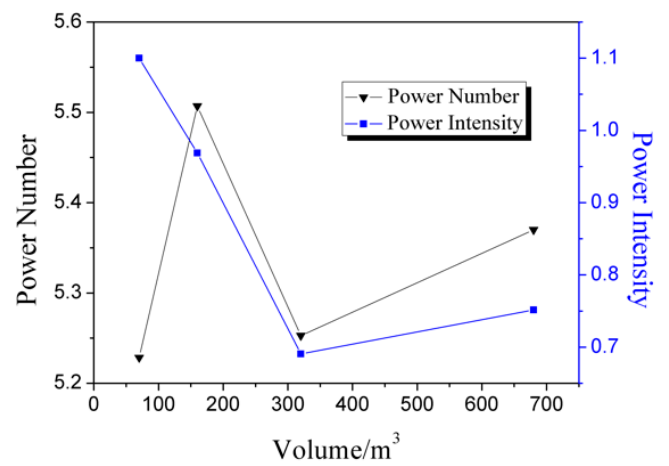

Figure 6. The relationship of volume, power number $N_{p}$ and circulation intensity. 
As illustrated in Figure 7, the circulation intensity decreases dramatically for cell volumes ranging from 70 to $130 \mathrm{~m}^{3}$. However, for cell sizes larger than $130 \mathrm{~m}^{3}$, the parameter varies a little and $F_{r}$ number also changes slightly, which indicates the similarity of the serial flotation cells.

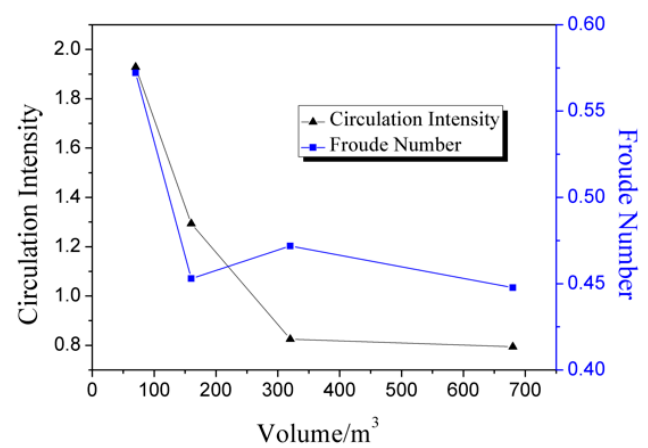

Figure 7. The relationship of volume, power intensity, air flow number $N_{a}$, and Froude number $F_{r}$.

It is easy to see that the air flow number and the air capacity number only fluctuate slightly with scale-up in Figure 8 . The air flow number is $\sim 0.002$, and the air capacity number is $\sim 15 \%$. The primary hydrodynamics numbers thus remained stable. In summary, the large BGRIMM flotation cell can maintain excellent hydrodynamic performance compared to the previous model, with different sizes that have been proven to be effective in engineering applications.

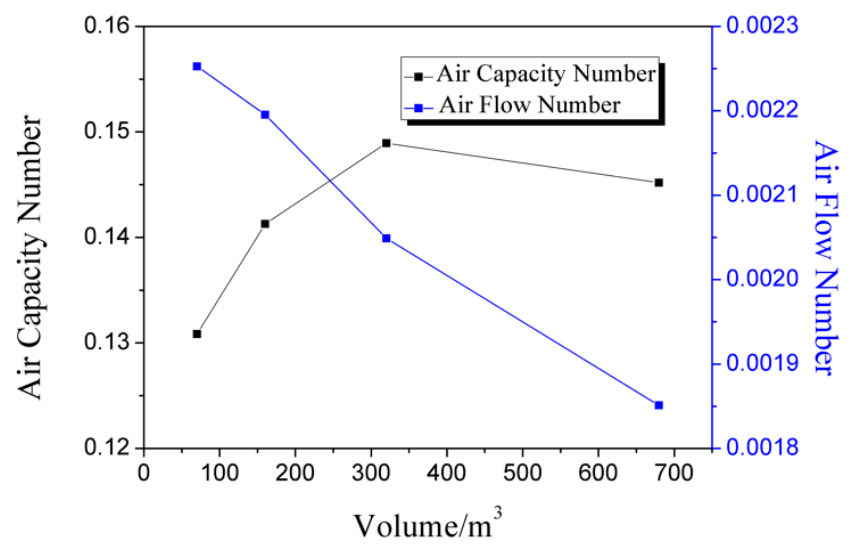

Figure 8. The relationship of volume, power intensity, air flow number $N_{a}$.

\subsection{Comparison of the Typical Impeller and the Arc Impellers}

\subsubsection{Comparison of Flow Pattern}

The tank height of the large-scale flotation cell is relatively larger, even though the scale-up of the flotation cell is based on geometric similarity. The greater tank height may increase the probability of detachment when mineral particles are transported in the large-scale flotation cell. Thus, a newly developed impeller, the arc impeller, was employed. The streamline at the center section of the flotation cell with the arc impeller is illustrated in Figure 9 with the same operation parameters and structural parameters. A change in the circulating flow was readily observed. Compared with the typical impeller in Figure 2, the low circulating flow becomes larger and reaches the tank wall. The flow pumping out from the arc impeller is obviously inclined upward where the flow produced by the typical impeller is nearly horizontal. The lifting of the streamline would shorten the distance for the transportation distance of mineral particles. Figure 10 also shows the turbulence eddy dissipation profile at the center section in the flotation cell to that of the typical impeller. The overall distribution is similar to the typical impeller (Figure 3), where large turbulence eddy dissipation appears around the impeller. 
The difference between the typical impeller and the arc impeller is the turbulence eddy dissipation profile outside the impeller. It is demonstrated that a change in the shape of at the impeller plate affects the flow and turbulence in the flotation cell. The impeller plate with a hyperbolic curve that cause smooth flow along the curves results in the variations.

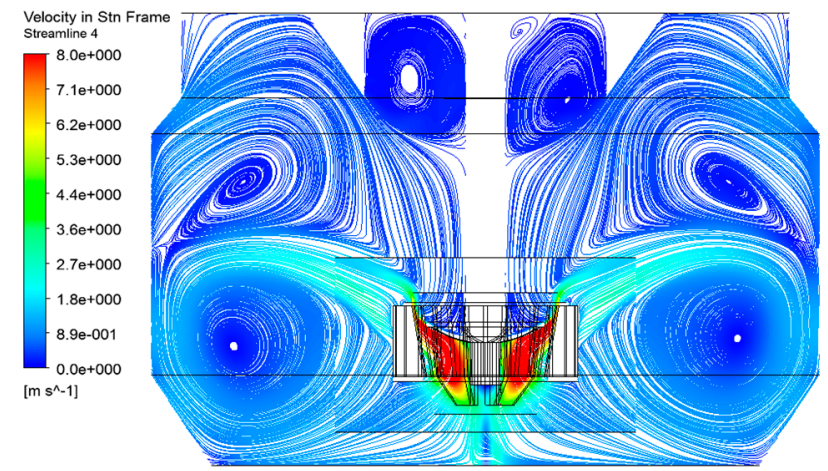

Figure 9. Velocity streamline profile at the center section in the flotation cell with the typical impeller.

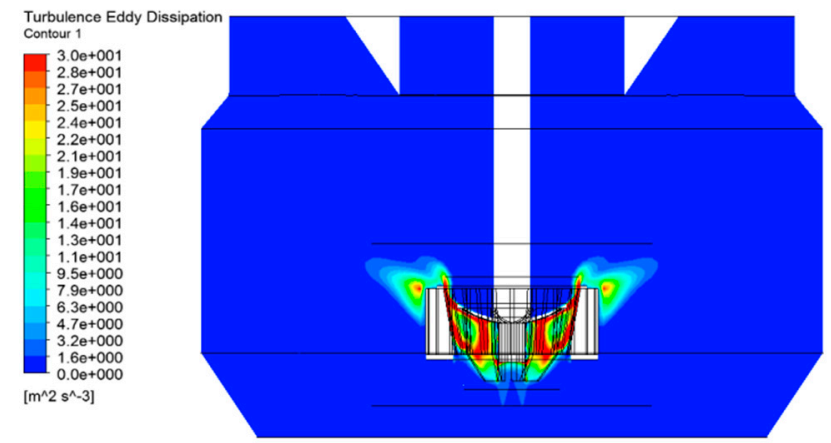

Figure 10. Turbulence eddy dissipation at the center section in the flotation cell with the arc impeller.

The line $r=1550 \mathrm{~mm}$ (the blue line) and $r=2750 \mathrm{~mm}$ (the green line) at the center longitudinal section was selected to show the different between the typical impeller and the arc impeller in Figure 11. Figures 12 and 13 show the radial and axial velocity comparisons, respectively, between the two types of impellers at the blue line and green line. The vertical coordinates value of $0 \mathrm{~m}$ is the bottom of the impeller plate. At the blue line, the axial velocity of the arc impeller is upward around the impeller. Thus, the velocity of the typical impeller is downward. It seems the arc impeller could push the slurry higher. At the green line which is far away from impeller, the different is much smaller. The axial velocity of the typical impeller is a little downward which the value is negative around impeller. For radial velocity comparison, the arc impeller shows greater radial velocity at the blue line than the typical impeller. 


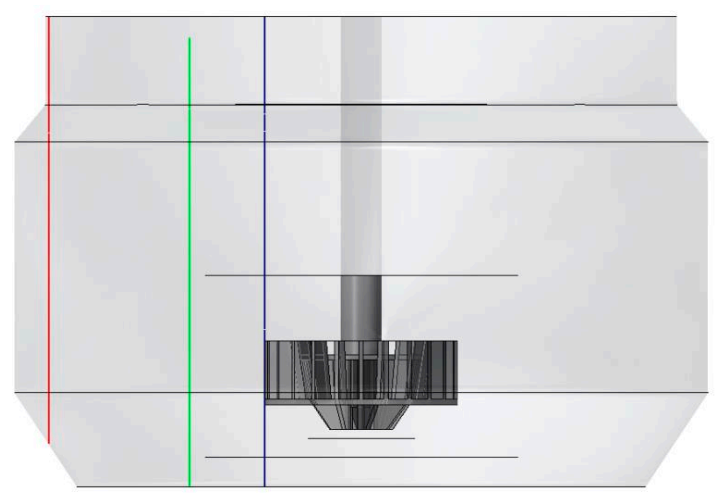

Figure 11. The line at the centre longitudinal section.

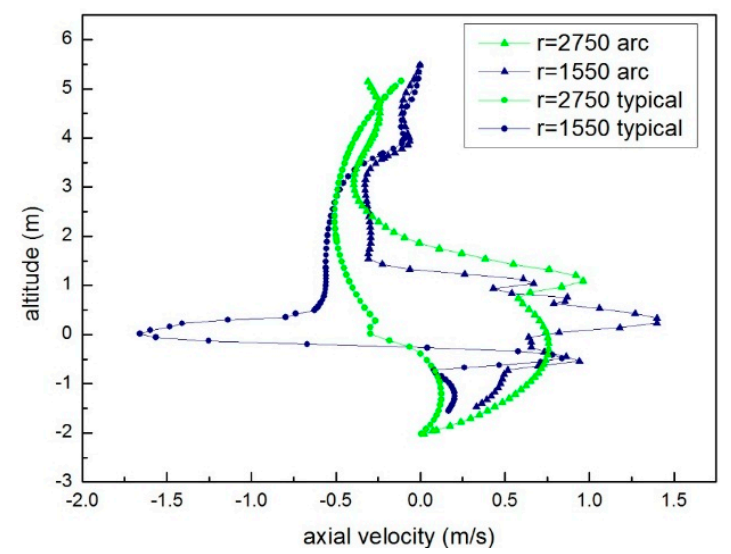

Figure 12. Axial velocity comparisons between two types of the impeller at the blue line and green line.

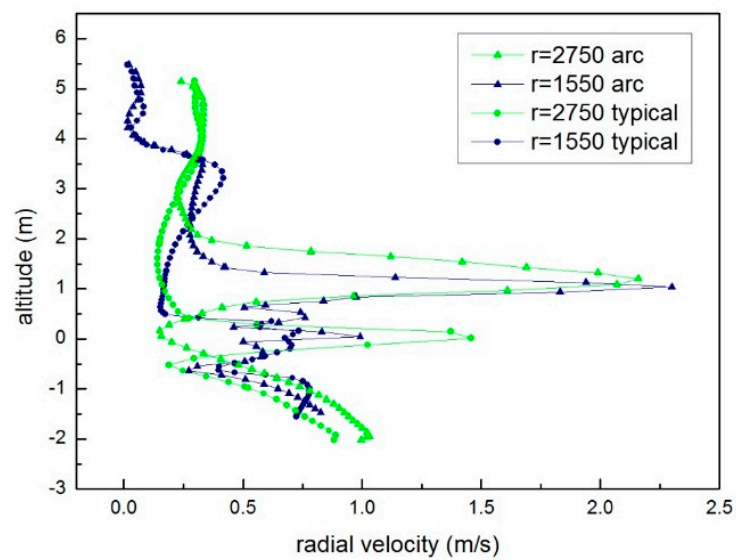

Figure 13. Radial velocity comparisons between two types of the impeller at the blue line and green line.

Figure 14 shows the turbulence eddy dissipation (TED) comparisons. The turbulence eddy dissipation is very small at the green line because the position is away from the impeller. No changes could be detected between two types of impellers. The turbulence eddy peak of the arc impeller is larger than that of the typical impeller. It also indicates that the arc impeller could push slurry higher. 


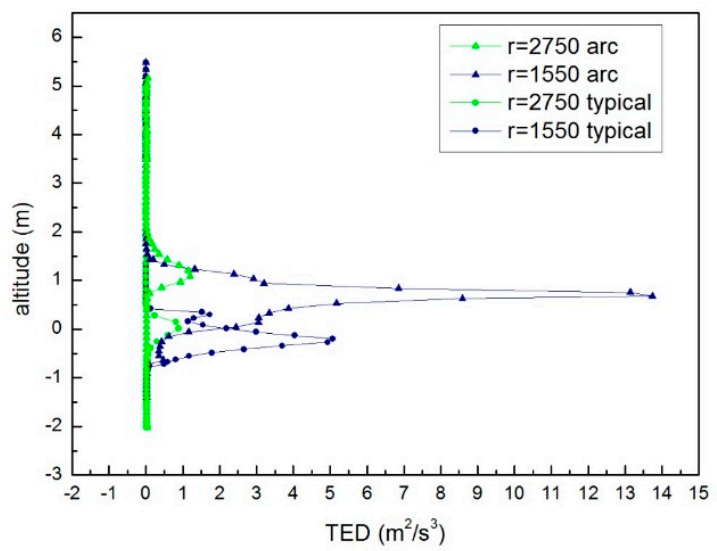

Figure 14. Turbulence eddy dissipation comparisons between two types of the impeller at the blue line and green line.

\subsubsection{Comparison of Flotation Kinetics}

The particle-bubble collision kernel $\left(z_{1}\right)$ is a key parameter for assessing the flotation kinetics. The collision kernel at the center section in the flotation cell with the typical impeller is indicated in Figure 15a. The collision kernel around the impeller and stator is larger than that at other regions of the flotation cell. The collision kernel for the arc impeller has a profile similar to that in the flotation cell in Figure 15b. It is also illustrated that outside of stator, the profile follows an upward tend $r$. The collision kernel maximum of the arc impeller is larger than that of the typical impeller. This means there will be a promotion in flotation kinetics.

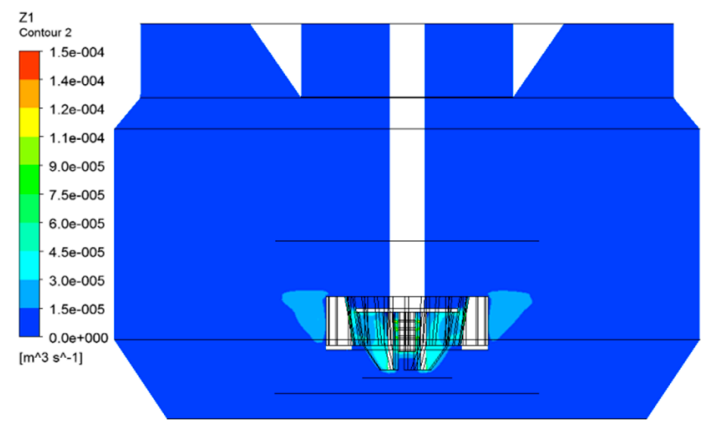

(a)

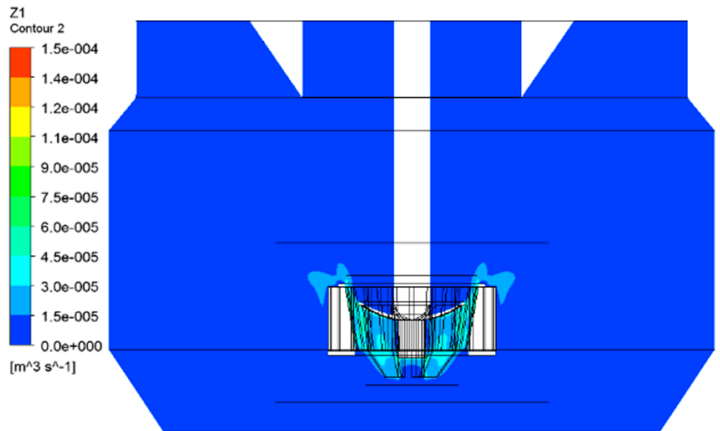

(b)

Figure 15. The collision kernel profile at the center section: (a) The typical impeller; (b) The arc impeller.

The collision probability is a significant parameter that directly reflects the metallurgical performance. The collision probability at the center section of the flotation cell is shown in Figure 16. The collision probability profile reveals the zone where the mineral particles mainly collide with air bubbles. There is a high collision probability in the impeller chamber. The impeller-stator zone and the outflow around the stator are the main zones for particle-bubble collision because the turbulence kinetic energy is also high in these regions. Compared with the turbulence eddy dissipation profiles in Figures 3 and 10, the profiles for the collision kernel and collision probability are similar in both the typical impeller and the arc impeller. Considering the flotation kinetics models proposed by Schubert and Bischofberger (Formulas (3) and (4)) [39], the turbulent eddy dissipation plays a critical role in the flotation kinetics. The difference in the collision probability profiles of the arc impeller is the same as the difference in the collision kernel profiles for the two types of impellers. The arc impeller gives rise to a higher collision probability than the typical impeller, leading to better metallurgical performance. 


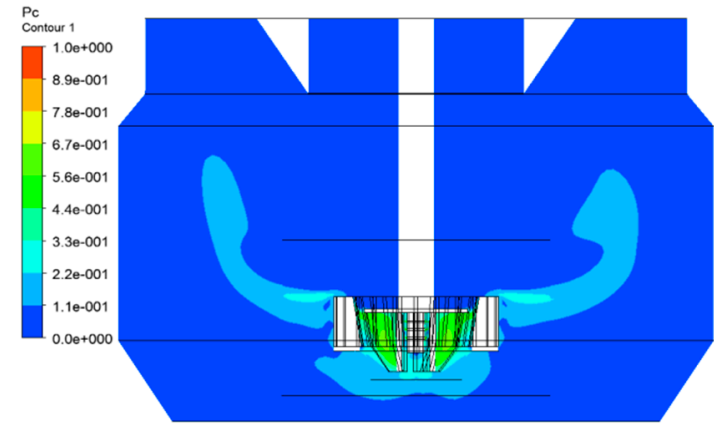

(a)

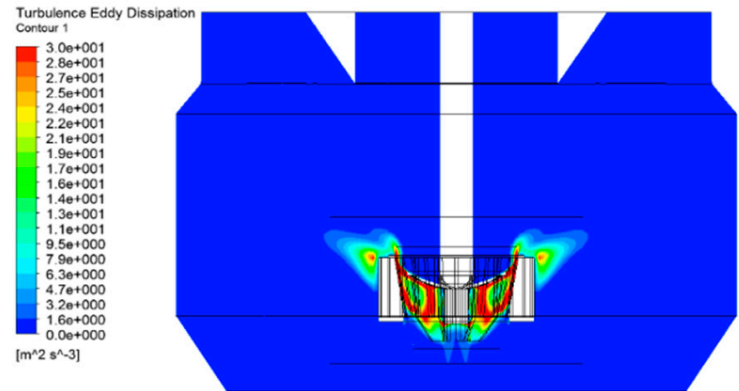

(b)

Figure 16. The collision probability profile at the center section in the flotation cell: (a) The typical impeller; (b) The arc impeller.

Figures 17 and 18 show the collision kernel and the collision probability comparisons, respectively, between the two types of the impellers at the blue line and green line. The collision kernel peak of the two types of the impellers appears the position nearby the similar height of the impeller region. It indicates the impeller is the source for the collision between mineral and air bubbles. The collision kernel peak of the arc impeller is higher than that of the typical impeller both at the blue line and the green line. It is similar characteristics with the variation of the velocity and the turbulence eddy dissipation. The attenuation of the collision kernel from the blue line to the green line is larger in the arc impeller. The collision kernel peak of the arc impeller is obviously smaller than that of the typical impeller at the green line. The variation trend of the collision probability is similar with that of the collision kernel.

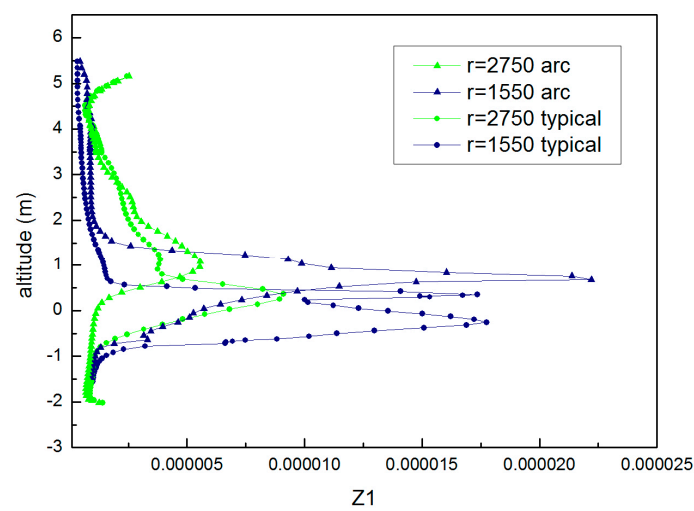

Figure 17. The collision kernel comparisons between two types of the impeller at the blue line and green line.

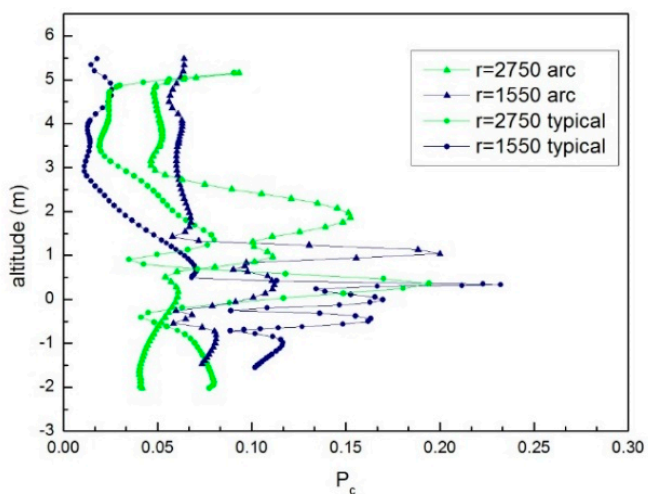

Figure 18. The collision probability comparisons between two types of the impeller at the blue line and green line. 
Table 6 summaries the comparison of the volume average parameters in the impeller region. The same trend could be observed about the volume average of the TED, $z_{1}$ and Pc. Compared with the typical impeller, the volume average of the arc impeller is a little smaller. Thus, the torque of the typical impeller is also larger than that of the arc impeller. Considering the lifting of the slurry higher, the arc impeller would be favor for the coarse particle recovery which a lower turbulence flotation environment is needed.

Table 6. Critical Parameters Comparison.

\begin{tabular}{cccccccc}
\hline $\begin{array}{c}\text { Volume Average of TED in } \\
\text { Rotor Zone, } \mathbf{~}^{\mathbf{2}} / \mathbf{s}^{\mathbf{3}}\end{array}$ & \multicolumn{2}{c}{$\begin{array}{c}\text { Volume Average of } \boldsymbol{z}_{\mathbf{1}} \\
\text { in Rotor Zone }\end{array}$} & \multicolumn{2}{c}{$\begin{array}{c}\text { Volume Average of } \\
\boldsymbol{P}_{\boldsymbol{c}} \text { in Rotor Zone, } \boldsymbol{\%}\end{array}$} & \multicolumn{2}{c}{$\begin{array}{c}\text { Torque of Rotor Zone, } \\
\mathbf{N} \cdot \mathbf{m}\end{array}$} \\
\hline Typical & Arc & Typical & Arc & Typical & Arc & Typical & Arc \\
\hline 33.0 & 17.2 & $2.4 \times 10^{-5}$ & $1.9 \times 10^{-5}$ & 31.9 & 25.4 & $54,280.6$ & $46,859.3$ \\
\hline
\end{tabular}

\section{Conclusions}

Scale-up of the flotation cell is required for the solution processing of low-grade mineral ores worldwide. This study was conducted on the latest and largest flotation cell in China, having an effective volume $680 \mathrm{~m}^{3}$, developed by BGRIMM. Multiphase flow numerical simulations were performed to investigate the hydrodynamics and kinetics of the large-scale flotation cell for further optimization and improvement.

The circulating flow is similar to that of the previous flotation cell. Good air dispersion and solid mixing in the flotation cell were demonstrated. The hydrodynamic performance parameters were analyzed with scale-up of the cell. The variation of the hydrodynamic numbers, such as the power number $\left(N_{p}\right)$, the Froude number $\left(F_{r}\right)$, the air flow number $\left(N_{a}\right)$, and so on, with the flotation cell volumes $\mathrm{g}$ follows trends similar to those of the previous cells of a different size that have been proven to be good for engineering applications.

To decrease the detachment of the mineral particles, a new type of impeller was developed (namely the arc impeller), where the impeller plate is a hyperbolic curve. The arc impeller expands and lifts the low circulating flow, thereby shortening the transportation distance of the mineral particles. Kinetic eddy dissipation plays a key role in determining the collision kernel and collision probability profile. The newly designed impeller leads to a higher collision probability than the typical impeller, leading to better flotation performance.

Author Contributions: conceptualization, Z.S. and S.S.; methodology, Z.S.; software, M.Z.; formal analysis, X.F.; investigation, M.Z. and D.H.; writing-original draft preparation, M.Z.

Funding: This work was supported by grants from the National Natural Science Foundation of China (No. 51474032 and No. 51674034).

Acknowledgments: The work was carried out at National Supercomputer Center in Tianjin, and the calculations were performed on TianHe-1 (A).

Conflicts of Interest: The authors declare no conflict of interest.

\section{References}

1. Yianatos, J.B.; Larenas, J.M.; Moys, M.H.; Diaz, F.J. Short time mixing response in a big flotation cell. Int. J. Miner. Process. 2008, 89, 1-8. [CrossRef]

2. Murphy, B.; Miettinen, T.; Yanez, A. Plant engineering and design experiences with the TankCell ${ }^{\circledR}$ e300. In Proceedings of the 27th International Mineral Processing Congress, IMPC 2014, Santiago, Chile, 20-24 October 2014; p. 265.

3. Shen, Z.; Lu, S.; Yang, L. R\&D and application of KYF large scale flotation cells developed by BGRIMM. Nonferrous Met. 2008, 4, 115-119. (In Chinese) 
4. Graul, R.; Nousiainen, M.; Yanez, A. Gas dispersion measurements in three outotec flotation cells: TankCell 1, e300 and e500. In Proceedings of the 27th International Mineral Processing Congress, IMPC 2014, Santiago, Chile, 20-24 October 2014; p. 265.

5. Lelinski, D.; Yang, Y.; Caldwell, K.; Rahal, K.; Traczyk, F.; Olson, T.; Jespersen, M. Advances in FLSmidth flotation. In Proceedings of the 11th International Mineral Processing Conference, Santiago, Chile, 21-23 October 2015; p. 176.

6. Mesa, D.; Brito-Parada, P.R. Scale-Up in Froth Flotation: A State-of-the-Art Review. Sep. Purif. Technol. 2019, 210, 950-962.

7. Koh, P.T.L.; Manickam, M.; Schwarz, M.P. CDF simulation of bubble-particle collisions in mineral flotation cells. Miner. Eng. 2000, 13, 1455-1463. [CrossRef]

8. Wang, G.; Ge, L.; Mitra, S.; Evans, G.M.; Joshi, J.B.; Chen, S. A review of CFD modelling studies on the flotation process. Miner. Eng. 2018, 127, 153-177. [CrossRef]

9. Koh, P.T.L.; Schwarz, M.P. CFD modelling of bubble-particle collision rates and efficiencies in a flotation cell. Miner. Eng. 2003, 16, 1055-1059. [CrossRef]

10. Xia, J.; Rinne, A.; Grönstrand, S. Effect of turbulence models on prediction of fluid flow in an Outotec flotation cell. Miner. Eng. 2009, 22, 880-885. [CrossRef]

11. Salem-Said, A.-H.; Fayed, H.; Ragab, S. Numerical simulations of two-phase flow in a Dorr-Oliver flotation cell model. Minerals 2013, 3, 284-303. [CrossRef]

12. Tiitinen, J.; Koskinen, K.; Ronkainen, S. Numerical modeling of an Outokumpu flotation cell. In Proceedings of the Centenary of Flotation Symposium, Brisbane, Australia, 6-9 June 2005; pp. 271-275.

13. Shi, S.; Zhang, M.; Fan, X.; Chen, D. Experimental and computational analysis of the impeller angle in a flotation cell by PIV and CFD. Int. J. Miner. Process. 2015, 142, 2-9. [CrossRef]

14. Koh, P.T.L.; Smith, L.K. The effect of stirring speed and induction time on flotation. Miner. Eng. 2011, 24, 442-448. [CrossRef]

15. Nelson, M.G.; Lelinski, D. Hydrodynamic design of self-aerating flotation machines. Miner. Eng. 2000, 13, 991-998. [CrossRef]

16. Arbiter, N.; Harris, C.C. Design and Operating Characteristics for Large Flotation Cells; SME Inc.: Littleton, CO, USA, 1979; p. 8.

17. Brander, B. Dimensional analysis and scale-up in chemical engineering. Von $\mathrm{m}$. Zlokarnik. Springer verlag, berlin 1991. 176 S., 51 Abb., geb., DM 38,-. Chem. Ing. Tech. 1993, 65, 457. [CrossRef]

18. Yianatos, J.B.; Henríquez, F.D. Short-cut method for flotation rates modelling of industrial flotation banks. Miner. Eng. 2006, 19, 1336-1340. [CrossRef]

19. Yianatos, J.; Contreras, F.; Morales, P.; Coddou, F.; Elgueta, H.; Ortíz, J. A novel scale-up approach for mechanical flotation cells. Miner. Eng. 2010, 23, 877-884. [CrossRef]

20. Yianatos, J.; Carrasco, C.; Bergh, L.; Vinnett, L.; Torres, C. Modelling and simulation of rougher flotation circuits. Int. J. Miner. Process. 2012, 112, 63-70. [CrossRef]

21. Yianatos, J.B. Fluid flow and kinetic modelling in flotation related processes columns and mechanically agitated cells-A review. Chem. Eng. Res. Des. 2007, 85, 1591-1603. [CrossRef]

22. Yianatos, J. Flotation rate distribution in the collection zone of industrial cells. Miner. Eng. 2010, 23, 1030-1035. [CrossRef]

23. Shen, Z. Principle and Technology of Flotation Machine; Metallurgical Industrial Press: Beijing, China, 2012.

24. Shen, Z.; Zhang, Y.; Han, D.; Feng, T. Application of KYF-320 flotation cell. In Proceedings of the 27th International Mineral Processing Congress, IMPC 2014, Santiago, Chile, 20-24 October 2014; p. 178.

25. Garcfa-Zuniga, H. Flotation recovery is an exponential function of its rate. In Proceedings of the 11th International Mineral Processing Conference, Santiago, Chile, 21-23 October 2015; Volume 47, pp. 83-86.

26. Finch, J.A. Column flotation: A selected review-Part IV: Novel flotation devices. Miner. Eng. 1995, 8, 587-602. [CrossRef]

27. Ahmed, N.; Jameson, G.J. Flotation kinetics. Miner. Process. Extr. Metall. Rev. 1989, 5, 77-99. [CrossRef]

28. Salem-Said, A.; Fayed, H.; Ragab, S. CFD simulation of a Dorr-Oliver flotation cell. In Proceedings of the SME Annual Meeting and Exhibit, Denver, CO, USA, 24-27 February 2011.

29. Tiitinen, J. Numerical modeling of a OK rotor-stator mixing device. In Proceedings of the European Symposium on Computer Aided Process Engineering, Kunming, China, 1-4 June 2003; Kraslawski, A., Turunen, I., Eds.; Volume 14, pp. 959-964. 
30. Shen, Z.; Chen, J. Flow Field Simulation and Its Applications; Science Press: Beijing, China, 2012.

31. Fayed, H.; Ragab, S. Numerical simulations of two-phase flow in a self-aerated flotation machine and kinetics modeling. Minerals 2015, 5, 164-188. [CrossRef]

32. Verrelli, D.I.; Koh, P.T.L.; Nguyen, A.V. Particle-bubble interaction and attachment in flotation. Chem. Eng. Sci. 2011, 66, 5910-5921. [CrossRef]

33. Koh, P.T.L.; Schwarz, M.P. Modelling attachment rates of multi-sized bubbles with particles in a flotation cell. Miner. Eng. 2008, 21, 989-993. [CrossRef]

34. Koh, P.T.L.; Schwarz, M.P. CFD modelling of bubble-particle attachments in flotation cells. Miner. Eng. 2006, 19, 619-626. [CrossRef]

35. Koh, P.T.L.; Schwarz, M.P. CFD model of a self-aerating flotation cell. Int. J. Miner. Process. 2007, 85, 16-24. [CrossRef]

36. Zhou, J.; Song, T.; Shen, Z. CFD simulation of gas-liquid flow in a large scale flotation cell. J. Comput. Multiph. Flows 2010, 2, 145-150. [CrossRef]

37. Abrahamson, J. Collision rates of small particles in a vigorously turbulent fluid. Chem. Eng. Sci. 1975, 30, 1371-1379. [CrossRef]

38. Schubert, H.; Bischofberger, C. On the optimization of hydrodynamics in flotation processes. In Proceedings of the 13th International Mineral Processing Congress, Warsaw, Poland, 4-9 June 1979; Volume 2, pp. 1261-1285.

39. Yoon, R.H.; Luttrell, G.H. The effect of bubble size on fine particle flotation. Miner. Process. Extr. Metall. Rev. 1989, 5, 101-122. [CrossRef]

(C) 2019 by the authors. Licensee MDPI, Basel, Switzerland. This article is an open access article distributed under the terms and conditions of the Creative Commons Attribution (CC BY) license (http:/ / creativecommons.org/licenses/by/4.0/). 